\title{
真空機器の保守・管理と安全
}

\author{
穂 坂 浩 之* \\ アルバックテクノ株式会社＼cjkstart恶253-8555＼cjkstart神奈川県茅ケ崎市萩園 2609-5
}

(2018 年 3 月 22 日受付；2018 年 6 月 18 日掲載決定）

\section{Safety and Maintenance Management for Vacuum Equipment}

Hiroyuki HosAKA*

ULVAC TECHNO, Ltd., 2609-5 Hagizono, Chigasaki shi, Kanagawa 253-8555, Japan

(Received March 22, 2018 ; Accepted June 18, 2018)

KEYWORDS : safty, maintenance, management, equipment

\section{1.はじめに}

現在, 私たちの生活環境で使用しているデジタル家電 機器, 食品, 医薬品, 自動車, 物流等は, 真空を作り出 す機器, 或いは真空を利用する機器が数多くある。今回 の講座では, 真空装置としてあるべき姿を想定し, 必要 な保守管理及び安全性について述べる。真空装置の安全 については, 先の後藤による講座『真空技術における潜 在的な危険と安全対策』1) も参照のこと。

可動部がある真空機器は, 「カバーを取り付ける」, 「手が入り込まないような構造とする」など安全対策が 施されるが, 施された安全対策に頼らず, 保守を行う作 業者も安全を意識して行動しなければならない。また, 保守を行わせる側も常に安全を意識して取り組む必要が ある。

現在出荷されている真空機器のうち, 生産用又は研究 用の装置は, 自動運転するものが多くを占める。想定さ れるトラブルが発生したとき, 或いは誤った操作を行っ たとき，インターロックが作動して装置は停止する。し かし, この停止状態は, 装置が自動運転を一時停止して いるだけであり, 圧縮空気, 冷却水, 電気などのユーテ イリティは供給されたままである。この状態で次に行う 作業を誤ると大きな事故につながる。

事故は保守作業者のみへの被害だけではなく, 設置場 所の環境を著しく污染する。時には他の製造装置や生産

*hiroyuki_hosaka@ulvac.com
中の製品に影響が及ぶことも留意されたい。

\section{2. 保守の考え方}

\section{1 故障曲線}

Fig. 1 に故障曲線（バスタブ曲線とも呼ばれる）を示 す。

真空装置, 或いは真空機器単体に使用されている部品 には, 機械部品, 電気部品として寿命がある。初期故障 期間として使い始めに故障が多い期間がある。現在で は，初期故障も各メーカーの過去からの経験や分析から 対策が施され, 最低限に抑えられている。しかし, 構成

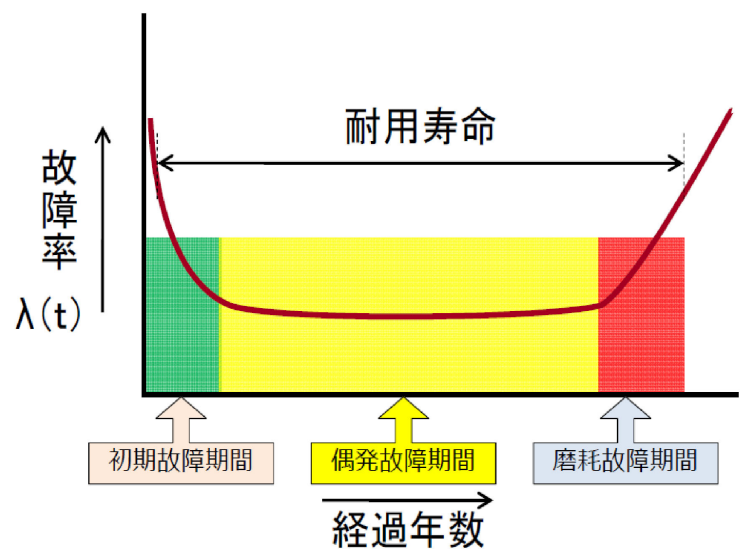

Fig. 1. (color online). バスタブ曲線の一例。 設備保全用語の一つである。装置の内部に使用されている各 機器には機械としての寿命があり, 寿命の期間で発生する故 障の頻度をグラフ化した図が有用である。これをバスタブ曲 線と呼ぶ。 


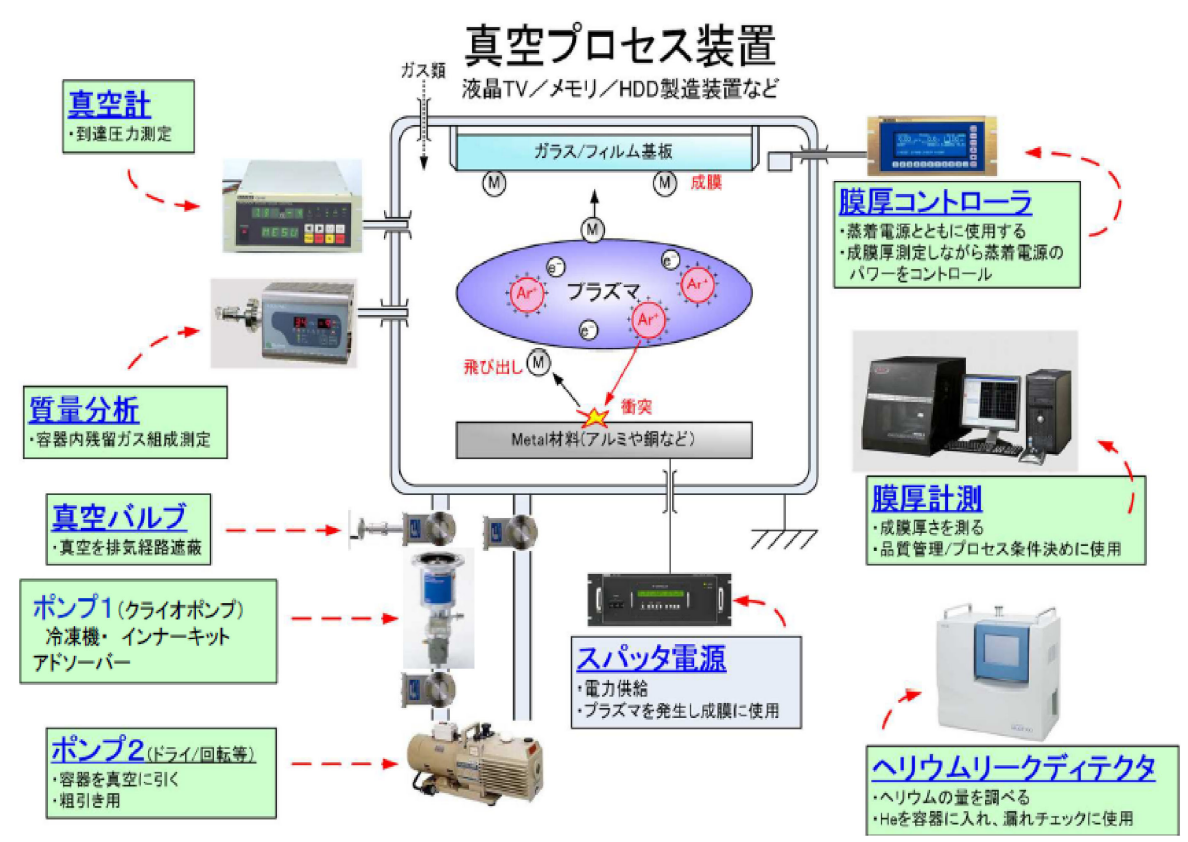

Fig. 2. (color online). 真空装置の構成例としてスパッタリング装置の略図。

される部品は, 全て同時期に寿命が来るのではなくそれ ぞれ時期が異なって故障が起き，都度事後保守を行う。 これを偶発故障期間と呼ぶ。さらに長期間使用し続ける と修理する部品数が増え, それらをまとめて行う予防保 全をしなければならなくなる。この期間を摩耗故障期間 という。この期間になると装置全体の定期予防保守が必 要となる。

保守の考え方は多数あるが，2つ紹介する。一つは, 偶発故障期間に定期的且つ計画的に予防保全として装置 を停止し，まだ摩耗故障期間までに至っていないが部分 的な保守が複数起きないようにして装置稼働率を上げる 方法。もう一つは, 装置に搭載されている機器の寿命を 把握したうえで, 各メーカーが推奨する保守の時間を超 えても，使用者側のリスクにおいて使用を継続するもの で, 故障したとき最小時間で保守を行ういわゆるダウン メンテナンスを選択する方法である。前者と後者には, それぞれメリットとデメリットがあるがどちらを選択す るか状況に応じて検討し決定する。

同じ仕様で納入された生産装置であれば，同様な周期 での保守でも良いが, 同じ構成の装置でも異なったプロ セスを行う装置では, それぞれの保守の周期が異なる。 例えば, 油回転真空ポンプの場合, 主排気系にターボ分 子ポンプを使用した生産用の真空装置を想定すると, 真 空容器の粗引き専用のものと, ターボ分子ポンプの補助 ポンプに使用しているものでは油回転真空ポンプの真空 ポンプ油の劣化具合は異なる。前者は, 大気, 真空を繰 り返すためポンプへの負荷が大きく, 大気圧中の水分を
排気する量が多い。後者はポンプ起動時の初動だけ負荷 があるが継続運転時の負荷が小さく, 真空ポンプ油の成 分変化が起こりにくい。

\section{2 保守に必要なこと}

真空装置・機器の保守を行う際に必要なことは以下の とおりである。

・各機器の構造や原理を正しく理解する

・装置, 部品メーカーの正しい手順を学び実施する

・必要な教育を受け, 資格を取得する

・安全に行う

油回転真空ポンプの保守においてでも，ただ分解して 復元することは, 何回か経験を積めば可能である。しか しなぜそのような構造なのか? その部品の役目は何か? なぜそのような順番に組み立てられているか? なぜその ような形状をしているのか？なぜその材質なのか？など を考えそれぞれの役目を正しく理解し, 正しい手順通り に行うことが大切である。

\section{3. 真空関連部品}

\section{1 真空装置の構成例}

真空装置（成膜装置）の構成例を Fig. 2 に示す。 Fig. 2 のなかで保守の対象となる機器を Table 1 に示す。

\section{2 保守の対象系統}

真空装置・機器の保守というと真空ポンプやバルブな どの機器を思い浮かべがちである。しかし, Table 1 で 示したとおり真空装置や機器を正常に運転するために は, 供給するユーティリティの保守を行うことが最も重 
Table 1. 保守の系統表例。

真空装置システム全体で保守の必要な部分を系統別で分類した。

\begin{tabular}{|c|c|}
\hline 系統 & 種類 \\
\hline 1 真空槽系 & $\begin{array}{l}\text { 真空槽, 真空シール部, 測定子, 防着板, 基板冶具, ターゲット材料（蒸発材 } \\
\text { 蒸発源, 各種電極, 駆動回転機構) など }\end{array}$ \\
\hline 2 排気系 & 真空シール部, 真空バルブ, 主排気・補助・粗引き用真空ポンプ, 配管類 \\
\hline 3 電気系 & $\begin{array}{l}\text { 中央処理装置 (Central Processing Unit：CPU） シーケンサー, 産業用 PC } \\
\text { (Factory Personal Computer : FA パソコン), 各種プロセス用電源, 制御電源, } \\
\text { 制御盤構成電気・電子部品・配線, 各コントローラー, センサー類など }\end{array}$ \\
\hline 4 付属機器 & 空圧，油圧制御機器， センサー類 \\
\hline 5 ユーティリティ系 & $\begin{array}{l}\text { 電気 (容量), 冷却水 (水圧流量, 温度, 比抵抗), 圧縮空気 (圧力と容量), } \\
\text { 真空槽大気開放用の窒素ガス又はドライエア } \\
\text { 各種プロセス用ガス類 }\end{array}$ \\
\hline
\end{tabular}

要である。電気の容量, 冷却水の量, 温度, 水質, 圧縮 空気, プロセスガスの純度, 供給圧力などが仕様通りに 供給されている必要がある。例えば規定の電気容量が供 給されないと装置内の各機器を正常に運転することがで きない。本稿では, Fig. 1のうち, 1 項, 2 項について 述べる。

\section{3 真空ポンプ}

各種真空ポンプを使用するうえで必要な保守や管理ポ イントを述べる。

\subsection{1 油回転真空ポンプ}

油回転真空ポンプは，真空ポンプ油の油膜でシリンダ 一内の真空気密を保つ。真空ポンプ油が劣化すれば, 油 膜が破壊し気密が徐々に破壊されて排気速度や到達圧力 を悪化させる。また，異物を吸気口から吸引したポンプ は，異物によりシリンダーとローター間のクリアランス が保てなくなったり, 異物が真空ポンプ油の循環系統に 詰まり, 潤滑不足となってポンプ温度が上昇し焼き付い てローターがロックしたりする。真空ポンプ油が循環不 良となれば真空シールを行っているエラストマーの温度 が上昇して, 熱劣化又は摩耗を起こし, 油漏れや真空漏 れを起こす。油回転ポンプの日常点検では, ポンプ油の 状態監視が重要であり, 特にポンプ起動時の電流值監視 は, ポンプへの負荷状態が把握できるので, 有効であ る。

\subsection{2 ルーツ真空ポンプ}

ルーツ真空ポンプにおいては, シリンダーへの異物混 入防止と補助ポンプの監視がポイントとなる。シリンダ 一内へ異物が混入すると, 油回転真空ポンプと同様にロ ーターのロックが起こる。これを回避するため吸気フィ ルターの定期的な点検が必要である。また, ルーツ真空 ポンプは, 背圧を維持するために用いる油回転真空ポン プや, ドライ真空ポンプの監視が同時に必要である。ま たポンプの仕組み上, 各ローター用ギヤ室の真空ポンプ 油は潤滑の役目をするのでその管理が必要である。

\subsection{3 ルーツ型ドライ真空ポンプ}

原理はルーツポンプと同様なのでシリンダー内へ異物 が混入するとローターがロックする。吸気口からの異物 混入防止が必要である。ポンプの運転状態監視の機能を 搭載しているものは, 運転中の電流值, 冷却水量, 本体 温度, シールガス（窒素ガス）の供給など監視ができる し，それぞれの上下限設定が可能でアラームを発報する ことができるので，それらを有効に利用するとよい。大 気を排気する為に使用する場合は問題ないが, 化学気相 成長法（Plasma Chemical Vapor Deposition：P-CVD）装 置やエッチング装置等でプロセスガスとして反応性ガス を使用する装置に搭載するポンプは, 反応性ガスが使え る仕様のポンプを選定しなければならない。プロセスガ スによりシリンダー内に生成物が堆積してロック現象が 起る場合がある。反応性ガスを排気したドライ真空ポン プを保守する場合, 保守の前に使用しているプロセスガ スの聞き取りを行い，そのガスに対応した無害化洗浄 (中和処理洗浄) を行ってから作業に着手する。保守を 依頼する側も保守を行う側も必ず確認する必要がある。 人的被害の防止や環境污染防止のためである。

\subsection{4 拡散ポンプ, 拡散エジェクタポンプ}

拡散ポンプ, 拡散エジェクタポンプでは, ジェットの 崟の隙間と形状, ボイラー抵抗值, 冷却水量と水温管理 がポイントとなる。ジェットの表面は多少污れがあって も性能に影響しないが, 傘の隙間が詰まると真空ポンプ 油蒸気の噴射量が変化し, 真空ポンプ油蒸気が壁に当た って冷却されたときに凝縮して気体を排気する一連の排 気の仕組みが不安定となる。また, 拡散ポンプも補助ポ ンプである油回転真空ポンプの監視が不可欠である。背 圧が臨界背圧を超えないように真空圧力を監視すること が重要である。

\subsection{5 クライオポンプ}

クライオポンプでは, ポンプ本体は冷凍機と各パネル の温度, 水素蒸気圧温度計の温度を監視することがポイ 
ントである。コンプレッサーは, 循環するへリウムガス の運転時の圧力範囲と停止時の圧力, 運転するために供 給される冷却水量と温度監視がポイントとなる。また, コンプレッサー内にはヘリウムガスの循環系等に油を捕 集するための吸着材が搭載されているのでメーカー推奨 時間で吸着材の交換が必要である。

ポンプ運用面では，スパッタリング装置などプロセス ガスを使用する装置に搭載されているものは, ポンプの 仕様にある気体の排気容量に達したらポンプの再生（溜 め込んだ気体をクライオポンプ外に再放出させてポンプ の性能を回復させる）を行う必要がある。イオン注入装 置などに搭載されたポンプは, 使用するガスの種類によ ってはポンプ本体を含め, パネル類の無害化洗浄や活性 炭パネルの交換が必要となる。これもドライ真空ポンプ と同様, 保守を行う前には, 何のプロセスガスを排気し たかを確認してからその対策を施して作業に取りかかる 必要がある。

\subsection{6 ターボ分子ポンプ}

ターボ分子ポンプは, 背圧を維持するための補助ポン プが必要であり, その圧力監視が必要である。また, ポ ンプ本体を冷却する機構（水冷の場合は, 冷却水, 空冷 の場合は冷却ファンの動作）を監視することがポイント となる。スパッ夕装置, 蒸着装置など軽負荷且つ不活性 なガスのみの排気に搭載されたものは, 保守までの期間 は比較的に長い。保守の内容は一般的には, 駆動系の消 耗品の交換を行うことで完了する。一方, CVD 装置, エッチング装置に搭載された場合は, 腐食性ガスを使用 するので, 保守の周期が短くなる。内容も駆動系の一般 的な消耗品の交換他に, ポンプ全体の無害化洗浄 (中和 処理洗浄), 本体や動翼, 静翼の再表面処理が必要であ る。腐食の状態により交換の可能性もある。

ターボ分子ポンプの故障で, 回転翼, 固定翼の損傷が 挙げられるが, 内部の翼の損傷は, 異物が入った時だけ ではなく, 吸気口或いは排気側からの大気圧導入や, 夕 ーボ分子ポンプが起動できる圧力より高い圧力の気体や ガスが流入し場合にも起こる。

\subsection{7 スパッタイオンポンプ}

スパッタイオンポンプは, 起動時に, 既にある程度の 圧力に排気されていなければならない。スパッタイオン ポンプの起動前に排気する真空ポンプ（油回転真空ポン プやターボ分子ポンプ）が正常に機能していることがポ イントである。それらのポンプが正常かどうかは, 3.3 .1 項や 3.3.6 項を参照していただきたい。

ポンプ本体の内部は, スパッ夕現象を起こす構造とな っており, ポンプ動作時は高電圧が印加される為, 保守 の前には, 必ずポンプ電源を遮断する。また電極内には
チャージアップしていることも想定されるので高電圧が 導入される電極をアース棒などで接地する。スパッタイ オンポンプは, 内部のカソード側（Ti 陰極）面がスパ ッ夕により削られるので定期的なセル（格子電極（陽 極）や Ti 陰極））の交換が必要である。

以上, それぞれのポンプの保守や監視事項について述 ベた。実務的には, ポンプ本体だけでなく, 周辺のバル ブも同時に点検又は保守を行った方が良い。これらが正 常な役目をしないとポンプ本体だけが正常でも, 真空排 気系として正常な運転をすることができない。

\section{4 真空シール}

真空シールには高真空領域までは一般的にエラストマ 一が使用される。エラストマーの寿命について, メーカ 一からは, フッ素ゴムなら 10 年前後, ニトリルゴムな ら 5〜 7 年前後と報告があるが，これは常温で使用した 場合である。使用する温度やプロセスガスに暴露される 環境により寿命は，加速的に短くなる。

エラストマーを固定シール（真空配管や真空槽の蓋 等）として使用する場合は, 真空グリースの塗布は行わ ない。エラストマー本体からの放出ガス以外, 放出ガス の発生源を増やさない為である。

エラストマーを運動シールとして使用する箇所（回転 軸シール或いは軸の摺動運動用シール）には, メーカー 指定の真空用の潤滑剂を塗布して気密を保つ。潤滑剂は 蒸気圧の低い真空グリースや真空ポンプ油を用いる。こ れらの潤滑剤でシールケースを満たし, 真空の気密を確 保する構造のものがある。これらの運動シール部分は, 使用当初は真空グリースや真空ポンプ油などの潤滑剤が 存在しているが, 回転数や摺動回数が増加していくとエ ラストマーの摩耗粉が生じ, 潤滑剤に混じってエラスト マーでの気密が保てなくなる。またエラストマーは, 長 期間使用すると硬化が始まる。潤滑剤にエラストマーの 摩耗粉やダストが混入したまま動作を継続するとエラス トマーの欠損や亀裂が生じることがある。これらを防ぐ ためには, 定期的な分解清掃と部品や潤滑剂の交換が必 要である。日常的には潤滑剤の補充や必要な個所への直 接塗布をおこなう。

超高真空領域以下の圧力では, 金属ガスケットが用い られる。金属ガスケットは, ナイフエッジ型のフランジ で無酸素銅製のガスケットを挟んで真空シールをするも の，アルミ箔ガスケットを専用フランジで挟んで真空シ ールするものがある。これらに共通する注意点は, 双方 のフランジのシール部の保護である。シール部が金属な ので一度傷をつけてしまうと修理は極めて困難である。 細心の注意で取り扱う必要がある。また, フランジを締 め付けるときは, 決められたトルクと順番で締め付ける 


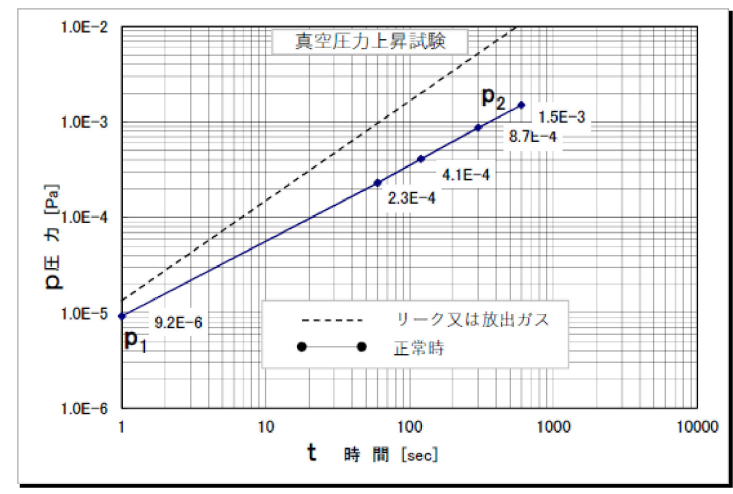

(a)

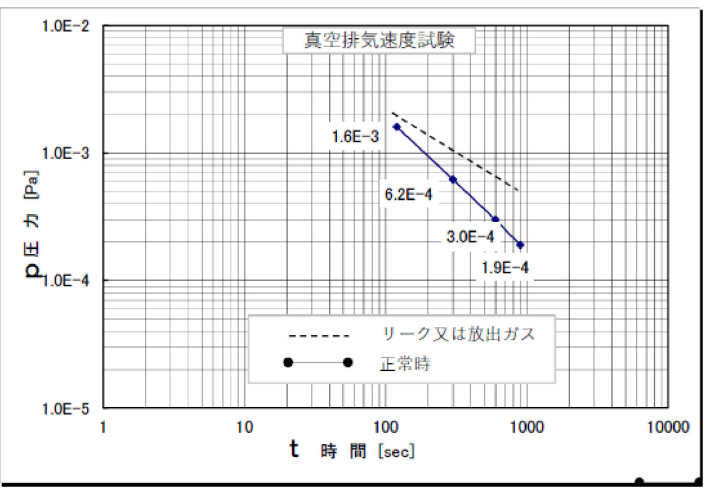

(b)

Fig. 3. (color online). (a) 真空槽の圧力上昇試験特性の一例。

(b) 真空槽の排気速度試験特性の一例。

（a）および（b）の点線は異常の状態下の特性を示す。真空槽に漏れがなく正常であれば，実線と同等な 特性となる。

ことが重要である。片締めしてしまうとシール面を損傷 してしまうことやリークする場合がある。

\section{4. 真空装置の管理}

まず，新規導入時の真空性能およびプロセス性能の記 録, ユーティリティの試験成績表, 保守図面を把握して おく。これらが以降の装置運用で性能に変化が生じたか どうかの判断の根拠となる。日常監視としては, ユーテ イリテイが仕様通りに供給されていること及び, 真空特 性の確認を行う。真空性能は, 真空圧力上昇試験, 真空 排気速度試験, 質量分析計による真空槽内の気体の分圧 試験等がある。

\section{1 圧力上昇試験 ${ }^{2)}$}

圧力上昇試験とは，真空槽をある一定の時間排気した 後に主排気バルブを閉じてある一定時間放置して，真空 槽の漏れ流量を測定する方法である。Fig. 3（a）のよう に到達圧力 $\mathrm{p}_{1}$, 主排気バルブ閉じて一定の時間後の圧力 を $\mathrm{p}_{2}$ としたとき, 真空槽の容積 $\mathrm{V}\left(\mathrm{m}^{3}\right)$, 経過時間を $\Delta \mathrm{t}$ （s）とすると式（1）が成り立ち, 漏れ流量 $\mathrm{q}\left(\mathrm{Pa} \cdot \mathrm{m}^{3} / \mathrm{s}\right)$ が求められる。漏れがある場合は, 一定速度で圧力が上 昇しグラフは右肩上がりとなる。

$$
\mathrm{q}\left(\mathrm{Pa} \cdot \mathrm{m}^{3} / \mathrm{s}\right)=\left(\mathrm{p}_{2}-\mathrm{p}_{1}\right) \times \mathrm{V} / \Delta \mathrm{t}
$$

\section{2 真空排気速度試験}

真空排気速度試験は真空圧力上昇試験を行った後に実 施することが効率的である。方法は, 真空槽に大気導入 して一定時間真空槽を大気圧にした後, その真空槽を通 常操作にて排気する。それを Fig. 3 (b) のように時間 に対する圧力としてプロットし, 粗引き時間と, 主ポン プでの排気時間を記録する。ある一定時間内に所定の圧

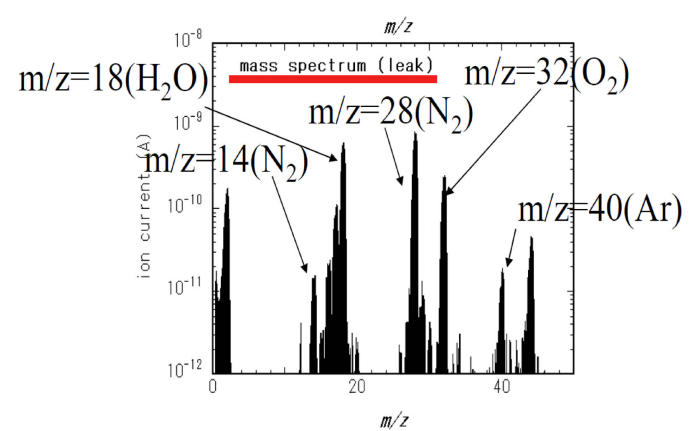

Fig. 4. (color online). 質量分析計で測定した分圧の事例。 真空槽の残留気体の分圧測定結果の一例を示した。 $\mathrm{m} / \mathrm{z} 50$ ま での測定結果を表示している。漏れがない真空槽を分子流ポ ンプで排気することで測定することができる。 ベーキングを実施しない場合，通常，残留気体として水分子 が残る。

力に達しない場合は, 真空槽の内, 外部リーク, 大量の 放出ガス発生が想定される。またこの試験の前に行った 圧力上昇試験で真空槽側のリークがなく正常な試験結果 だったが，排気に時間を要している場合は，真空排気系 の何処かの箇所に要因があると推定できる。この場合ポ ンプの点検を 3 項の要領で行う。

\section{3 質量分析計による真空槽内の気体分子の分圧 ${ }^{2)}$}

一般的に真空槽を大気圧から排気し，真空槽のベーキ ングを行わない状態を質量分析計でマススペクトルとし てモニターすると水の分子の信号強度が高く検出される (Fig. 4)。しかし, 外部からの漏れがあった場合は，大 気が流入するため窒素, 酸素分圧が大気組成の分圧比で マススペクトルに現れる。（大気圧の組成は窒素 $78 \%$, 酸素 $21 \%$ ，アルゴン $0.9 \%$ ，その他 $0.1 \%$ ）内部リーク 
Table 2. 必要なトレーニング例 ${ }^{3)}$ 。

真空機器を保守するために必要な教育やトレーニングの一部を抜粋した。この他も労働安全衛生法で定められた特別教育として 多数ある中で保守を行う内容，環境に応じて特別教育を受けなければならない。

\begin{tabular}{|c|c|}
\hline 訓練の種類 & 教育・トレーニング \\
\hline 装置・部品 & メーカーによる装置及び機器のトレーニング \\
\hline 保護マスク & 防塵と防毒マスクの使用目的の違いの理解，装着の仕方，使用期限や日常的な管理の仕方 \\
\hline プロセスガス & SDS の現場への設置と内容の理解。 \\
\hline 安全帯 /他保護具 & 装着する手順，注意点。使用期限の把握 \\
\hline 重量物 & 人が持ち上げてよい荷重の把握。荷役運搬器具の使用方法，資格の必要性の有無（クレーン，玉掛け \\
\hline はしご・脚立 & はしごの掛け方，角度，脚立に載って作業するときの姿勢や使用可能な段数の把握 \\
\hline 産業用ロボット & 資格を取得後に実施することができる産業用ロボットの教示・検查業務に係る作業。 \\
\hline 持別教育 & 電気取り扱い（低圧，高圧，特別高圧），酸素欠伦危険作業，粉塵，研削砥石，特定化学物質等 \\
\hline
\end{tabular}

としてガス導入口のバルブの内部から供給されるガスが 漏れ出ている場合は, そのガスの值が大きく表示され る。

漏れ探しを行う場合，一般的にはへリウムリークディ テクターを使用して箇所を特定する。質量分析計が運転 できる圧力範囲であればへリウムリークディテクターの 代用として，質量分析計を使うことができる。

上述の 3 つの試験を行うときに注意すべきことは, 試 験を行うときの条件を常に一定にすることである。正常 時にとった試験データと相対比較するため, 条件が異な っていると, 正常, 異常の判断ができない。一定にする 条件とは, 真空槽を排気する時間, 真空槽内の状態（具 体的には内容物が同様であるか, 加熱するかしないか, 保守で部品交換の前か後かなど）等である。

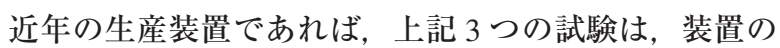
保守用の画面上にて自動で行えてモニターできるものが 多い。しかし機能として持っていない装置も多数存在す る。そのときには, 本手順で継続的監視を行うことを推 奨する。

また, 質量分析計は, 常に真空槽に取り付けた状態 で, 定期的にその分圧状態をモニターすることが重要で ある。装置へ質量分析計を取り付けるときにはプロセス での污染を防止し，質量分析計内を真空状態に保持する ことができるように，バルブを介したほうがよい。必要 な時にバルブの開閉でモニター出来ることが望ましい。

\section{5. 真空機器・装置取り扱い時の作業の安全}

\section{1 保守作業時の注意事項}

保守を行うためには装置・機器メーカーが行う, オペ レーションや保守のトレーニングを受け，訓練すること が必要である。訓練とは必要な教育を受講したあと, そ れが出来るかどうか繰返し行うことである。例えば保護 メガネが必要な作業で, 髪の毛を挟まず正しく装着でき るかどうか, マスクの種類として防塵用と防毒用の違い
を理解しているかどうか等である。必要な時に正しく使 用できる様に日頃から訓練を行うことが大切である。

\section{2 必要な教育・トレーニング}

必要な教育や訓練は, Table 2 を参照されたい。例え ば電気を取り扱う保守作業を行う場合は，扱う機器の電 圧の容量により必要な教育を受講することが必要であ る。安易な電気の知識だけで扱ってはならない。

\section{3 安全データーシート（Safety Data Sheet：SDS） の設置3)}

扱う材料や物質などその製品情報が掲載されている SDS には様々な情報が記載されている。製品情報として 絵表記（ピクトグラム）化学物質の分類及び表示に関す る世界調和システム (Globally Harmonized System of Classification And Labeling of Chemicals : GHS) が掲載さ れているので先ず何に注意するべきかを把握できる。処 置方法に関する情報が記載されているので, 誤ってその 化学物質を吸引したなどの緊急時 ${ }^{3}$ に応急処置ができる ことと救急隊にSDS を提示することで速やかに適切な 処置が施される。他にも組成や管理方法などが掲載され ているため, 適応した法律に遵守した管理を行うことが できる。

\section{4 危険なエネルギー源 ${ }^{3)}$ 遮断}

一般的に危険エネルギーとして想定されるものは, 電 気, 機械, 化学, 圧力, 放射, 温度が挙げられる。 （Table 3）保守を行う場合, 行う箇所や関連個所の危険 エネルギーを遮断してから作業を行う。ここでは, 電気 に関する事例を紹介する。

例えば，ある機器を交換する作業をする前には，その 専用ブレーカーを遮断してから作業にはいる。しかし そのブレーカーを作業者当人が遮断しても第三者に よって供給されるかもしれない。そのような事故を 防ぐため, 作業者を保護する為にロックアウト, 夕グ アウト（Lockout Tagout：LOTO）処置を行ってほしい $(\text { Fig. 5 })^{4)}$ 。ブレーカーを遮断した後, ブレーカーを ON 
Table 3. 危険エネルギー源例 ${ }^{3)}$ 。

装置に供給されるエネルギー又は，装置内で発生するエネルギーを種類別に分類した。

\begin{tabular}{ll}
\hline 種類 & \multicolumn{2}{c}{ 残留又は発生個所 } \\
\hline 電気 & 端子台・配線・コンデンサ・電池（バッテリー） \\
\hline 化学 & 薬液タンク, ガスボンベ, ガス配管, バルブ, マスフローコントローラー, 真空槽 \\
\hline 機械 & 回転部, モーター, フライホール, バネ \\
\hline 放射 & UV (紫外線) ランプ, 反応性ガス使用の真空槽内の電極, X 線発生器, レーザー発生器 \\
\hline 圧力 & エアシリンダ, タンク, 油圧容器, 加圧ポンプ, 真空ポンプ \\
\hline 温度 & ヒーター, 液体窒素容器, 熱放射体 \\
\hline
\end{tabular}
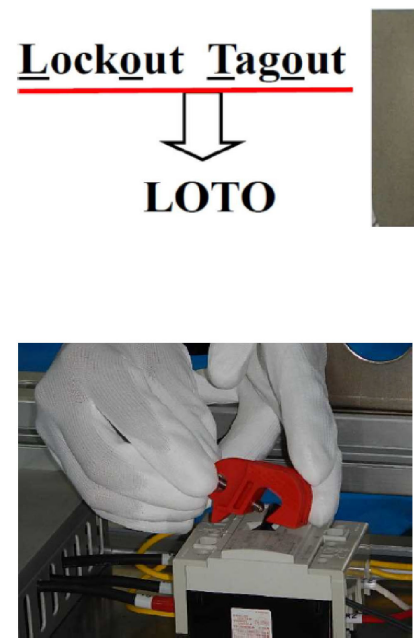

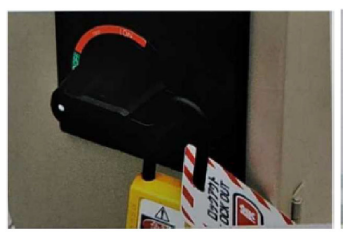

(a)

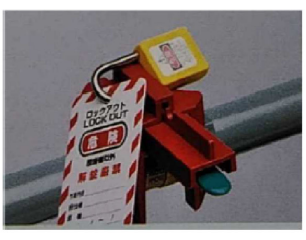

(b)

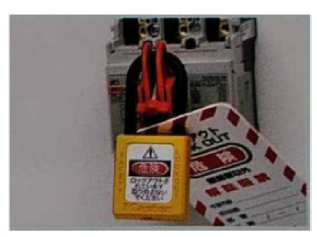

(c)
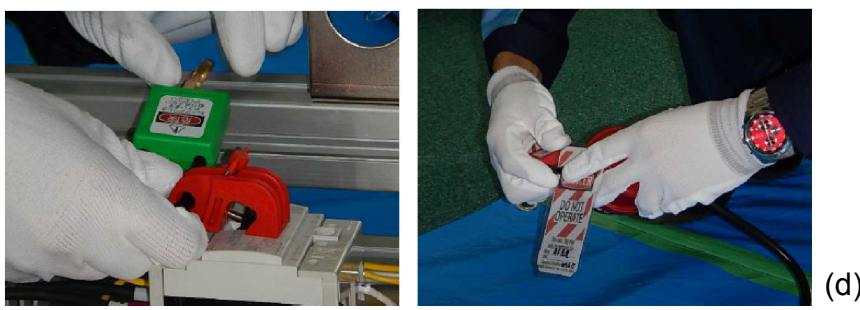

Fig. 5. (color online). Lockout Tag out（LOTO）の種類と事例。 LOTO で使用する器具の一部として
(a) ブレーカー用 LOTO で使用する器具例。
（b）圧縮空気又は冷却水用に使用するバルブ用 LOTO で使用する器具例。
(c) ブレーカー用 LOTO で使用する器具例。
（d）実際にブレーカーにロックアウトを行い，タグアウトしている状態を示した。 タグにはロックアウトをした人の氏名や連絡先が記載される。

にできないようにする治具を取り付け，更にその治具に 施錠を行う。鍵を開けないと治具を取り外せないような 機能となっている。また鍵には施錠者名を明記する。そ れらを使用することで第三者によって誤ってブレーカー が ONされることを防げる。このように危険エネルギー 源を遮断した後, 作業者一人の場合も複数の場合も全員 の鍵がないと遮断解除を行うことができない仕組みにな っていることが重要である。

\section{5 インターロッグ)}

自動運転を有する装置には，各操作を行うスイッチに インターロックがかけられている。インターロックはソ フトウェアやハードウェアによって安全確保と装置・設 備を安定に稼働させるために常に装置の状態監視をする もので，異常が発生した場合に緊急停止やアラームを発 報して機器を保護するものである。インターロックが動 作した時や緊急時には, フェールセーフ（システムが, 起こりうる誤作動や誤操作に対して安全な方向に動作す
ること。また，それを実現しようとする設計または，設 計思想のこと。）として停止する。但し，これは 5.4 項 で述べた様に危険エネルギーを排除するものではないの で，この状態で保守を開始してはいけない。

\section{6 大気開放時の注意 ${ }^{3)}$}

真空装置の大気開放時に導入するガスとして窒素ガス を用いる場合がある。窒素ガスを使用するメリットは, 無臭で不活性且つ水分量が大気圧と比較して少ないこと である。しかし, 真空で保持された真空槽に, 窒素ガス を導入して大気圧に戻した直後, 保守の為に真空槽に顔 を入れて一呼吸した瞬間に一時的な酸欠状態となる危険 性がある。それがまだ軽度であればよいが，気絶して倒 れて何かに接触や転倒して起こる二次災害を起こす危険 性がある。装置の規模が大きい方が危険度は増す。大気 開放用に窒素ガスを使用する場合は十分な換気をするこ とと酸素濃度計で確認してから行うことが必要である。 


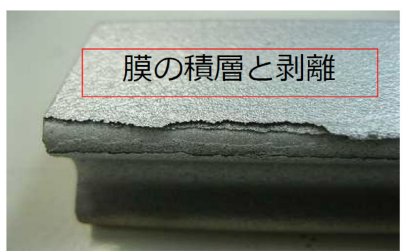

(a)

粉じんの種類による爆発しやすさ度

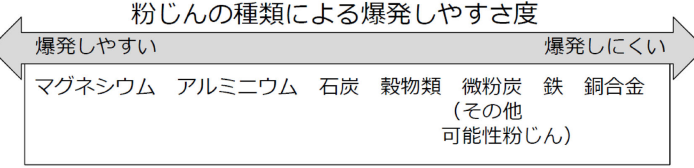

Fig. 6. (color online). 成膜装置シールドの薄膜堆積状態と危 険性。

(a) 成膜装置に搭載されている防着版に薄膜が何重にも積層

し，膜の応力で剥離した状態を示した写真。

(b) 材料の種類による粉体爆発のしやすさを表している。 粒径が小さいほど, 量が多いほど爆発しやすくなるので粉体 爆発を防止するためには掃除機などに溜めないことが重要で ある。

\section{7 真空槽内清掃時の注意}

真空装置のクリーニングとしてプロセスを行う真空槽 をよく掃除機で清掃することがある。スパッ夕装置の夕 ーゲット周りの保護のために扔かれるシールドや防着板 に堆積した膜が剥離し, 細かい粉末状になったものを掃 除機で吸引する場合には注意が必要である。(Fig. 6)。 真空中にあった金属粉を大気に触れさせそれを大量に吸 い込むと掃除機内で粉塵爆発を起こす危険性がある。金 属の種類によっては発火性の高いものがあるので注意が 必要である。これの対策としては, 掃除機には溜めない こと, クリーニングが終了したら都度別の金属粉末保管 容器で保管すること, 防爆型の掃除機を使用することな どがあげられる。

また, 本来堆積している膜が剥離し始めている時点 で, すでに堆積の限界を超えている。剥離し始める前に シールド類を定期的に除膜洗浄し再生処理することをす すめる。除膜方法は様々であるが機械研磨や薬液による 除膜など堆積された材料に合った洗浄方法で, 再生処理 を行う必要がある。(Fig. 7 参照)

\section{8 作業者の心構えとルール遵守}

保守を行う作業者は, 一人一人の心構えとして以下を 留意してほしい。

・作業前に危険の洗い出しと対策を行う

・作業場の 5S（整理・整頓・清掃・清潔・㷣）を遵 守する

・取り扱う製品, 装置の基本知識, 操作方法など保守 図面や作業手順を確認する

・緊急時の避難経路や安全設備, 連絡先などの確認を 明確にする。

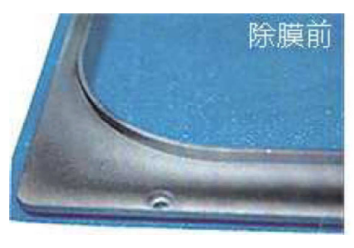

(a)

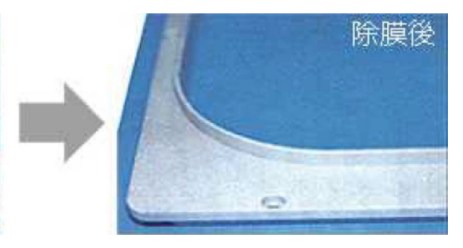

(b)
Fig. 7. (color online). シールドの洗浄。

(a) 成膜装置に搭載されている防着板の洗浄前の高融点金属 が付着した部品の写真。

(b) (a) の部品の付着高融点金属のみを洗浄除去した後の 写真。

薄膜装置で皘層された膜は, 防着版の母材と皘層した膜の材 質にもよるが, 精密洗浄（機械研磨又は化学研磨）を行い,

防着板を再生することが可能である。どのくらい積層したら 剥離するか装置メーカーと相談し, 剥離する前に交換して再 生処理を繰り返し使用する方法が好ましい。

\section{・十分な体調管理を行って臨む。}

また, 様々な保守作業にあたっては法令, ルールを遵 守することが求められる。『労働安全衛生法』が労働者 の安全と健康を確保する目的の中心法令となっている。 それらが何の為に定められているのかをよく理解し, 守 ることが大切である。

\subsection{1 危険予知活動}

保守作業を行う現場には様々な危険が潜んでいる。普 段同じ装置を目にして操作をしていても実際に保守を行 おうとした時, 初めて危険だと気付く場合もある。保守 する対象物が実は予想より重量物であった，狭くて暗い 場所に設置されている, 高電圧用の電源を外さないと引 き出せない，などの事例は少なくない。

一人作業は原則行わないが, 一人の場合も複数人の場 合も以下のように危険予知活動を進めることが必要であ る。

・どのような険が潜んでいるか作業者するもの全員が 考え，探し出す

・洗い出した危険要因のうち重要部分を把握し対策す る

・行動計画を立て, 全員で共有する

これらは, 誰かに行ってもらうものではなく, 一人一人 の責任において自身が害施するものである。

\subsection{2 リスクアセスメント ${ }^{4,5)}$}

作業を行う前には前項で述べたように危険予知活動を 行う。リスクアセスメントは, その危険予知活動の過去 の危険事例やヒヤリハット事例を通して作業の計画段階 から危険源を特定し, 危険查定を行ってリスクを最小限 にして作業を行う手法である。5.4 項, 5.5 項に上げられ た危険源に加え, 騒音や振動, 人間工学的な観点, 使用 環境，作業を組み合わせた場合の危険源など多角的に見 
て分析する。そして作業に扔けるリスクを抽出する。手 法には, リストグラフ法やマトリクスス法, 加算法があ る。ここでは加算法を紹介する。リスクの見積を危険の 程度, 危険が起こる可能性, 怪我をしたときの時の重篤 度をそれぞれ低い方から高い方へ数值化し，それぞれ查 定で使用した数值の合計が高いほどリスクが高く優先的 にリスク対策を行う対策を行った上でもう一度そのリス ク查定を行う。合計数值が 0 になることはまずないがリ スクを下げることで, 災害発生時のリスクを最小限に抑 えることが出来る。それでも過信せず気を抜かずに作業 を行うことが必要である。また, リスクアセスメンテ は, 保守をするときの現場だけ行えばよいものではな い。リスクアセスメントの考え方はすべての仕事に生か すことが出来る。

\section{6. ま と め}

以上, 真空機器の保守・管理と安全について述べた。 真空機器の保守を行わせる側は, 必要な教育を受けさせ る義務があり, 行う側も教育を受けなければならないと いう意識を持つことを忘れてはならない。教育を受けて 正しい知識とルールを認識したうえで自らが自発的に安 全に対する取り組みを行ってほしい。1回受けたからと 過信をしないで繰り返し受けた教育から訓練を行ってい ただきたい。

今後, 周辺機器が Internet of Things（IoT）により進化
していく中で真空装置も制御系，ハード系もそれに対応 したものになっていく。それに伴い保守の方法も IoTを 駆使した方法が必要になるであろう。装置が自己診断 し，判断までするようになるであろう。それでも作業者 がロボットにならない限りその先にある必要な保守は人 間が行わなければならない。

最後に, 繰り返しお願いする。装置を扱う全ての方 は, 安全を常に意識し, 行動してほしい。自分の身は, 自分で守る。事故を防ぐ最後の砦は自身の行動であり, 日頃の安全に対する習慣が左右する。

\section{文献}

1) Y. Gotoh : J. Vac. Soc. Jpn. 59, 184 (2016). (in Japanese)

2) 中山勝也 : “新版真空技術実務読本” 竹生修已編 （株式会社オーム社, 東京, 1994） p.92-94, p.148149.

3) SEAJ (一社) 日本半導体製造装置協会: SEAJ 推奨 サービス安全教育・テキストR.4.00, 東京 (2017 年 4 月 1 ).

4) ミドリ安全株式会社 商品カタログ LOCKOUT SYSTEM CATALOG VOL.6（2015 年発行 A270743-1 05K）p.12 右下 (1) 外部ハンドルへの使用例, (4)PSLCBILNT の使用例, p.17右下 (5) ボールバルブ使用 例.

5) JIS B 9700:2013 機械類の安全性 一 基本概念, 設計 のための一般原則 — リスクアセスメント及びリ スク低減. 